\title{
Stages of Concern of Grade 8 Teachers in K to 12 English Curriculum: Basis for the Development of a Training Program
}

\author{
Winicel May C. Ancheta and Ronald Candy S. Lasaten
}

\begin{abstract}
Using the Research and Development (R\&D) methodology, this study aimed to develop a proposed training program to address the concerns of 70 Grade 8 teachers in the implementation of the $\mathrm{K}$ to 12 English Curriculum, as a result of the analysis on the stages of concern of the teachers. Data on socio-demographic profile of the teachers were analyzed using frequency, percentage, mean and standard deviation, while their stages of concern were analyzed and interpreted using frequency, percentage, and Peak Stage Score Interpretation. Meanwhile, Pearson's r correlation was used to determine the relationship between the teachers' stages of concern and their socio-demographic profile. Mean was used to determine the validity of the proposed training program. Findings show that the teachers' stage of concern is at Stage 0 (Awareness). The teachers' stages of concern have a significant relationship to the teachers' age, years of teaching experience, educational attainment, and number of trainings and seminars attended related to the $K$ to 12 English Curriculum. The proposed training program is valid in terms of its rationale, objectives, content and methodology, manpower resources, budgetary allocation, and evaluation instrument.
\end{abstract}

Index Terms-Concerns-based adoption model (CBAM), K to 12 English curriculum, stages of concern (SoC), training program.

\section{INTRODUCTION}

Today, most governments invest heavily in education as a proportion of their total budget since they tend to see educational process as a primary means of producing the sort of intelligent and skilled workforce required to operate in the changing environment at all levels of the economy. Therefore, a period of expansion and change in many public educational systems is being experienced throughout the world, as governments implement the sort of educational programs that achieve their aims. The change is represented by increased access to education at all levels, and a consequent re-thinking of the aims, objectives, and manner of delivery of the curriculum.

Indeed, education equips individuals with the necessary knowledge and skills they need to become functional members of a society. Education can also be one of the strongest instruments for reducing poverty, thereupon improving the well-being of the people. However, to

Manuscript received June 1, 2017; revised September 5, 2107.

W. M. C. Ancheta is with the Ilocos Norte College of Arts and Trades (INCAT), Laoag City, Ilocos Norte, Philippines (e-mail: winicelmayancheta@gmail.com).

R. C. S. Lasaten is with the Mariano Marcos State University College of Teacher Education (MMSU-CTE), Laoag City, Ilocos Norte, Philippines (e-mail: ronaldlasaten@gmail.com). establish and maintain a high-quality education system, proper investments must be made.

In the Philippine context, education remains a top priority. Despite the various development plans and projects formulated by the government and the different sectors, the quality of Philippine education still leaves much room for improvement. As part of the efforts of the present administration to respond to the perceived needs of the education sector, the Department of Education (DepEd) has pushed for the implementation of an innovation, the "Enhanced K to 12 Basic Education Program."

The " $\mathrm{K}$ to 12 " stands for kindergarten plus 12 years of elementary and secondary education. This educational system for basic and secondary education is widely adopted around the world. The Basic Education Sector Reform Agenda, as a package of reform initiatives, considers K to 12 as the flagship reform strategy. As stated by [1], the objective of the program is to produce more productive and responsible citizens equipped with essential competencies and skills for both life-long learning and employment.

From among various proposals and studies conducted to come up with an enhanced model that is suitable to the Philippine context, DepEd proposed the K-6-4-2 model or the $\mathrm{K}$ to 12 model. This model involves kindergarten, six years of elementary education, four years of junior high school (Grades 7-10), and two years of senior high school (Grades 11-12). The two years of senior high school intend to provide time for students to consolidate acquired academic skills and competencies. The said curriculum would allow specializations in science and technology, music and arts, agriculture and fisheries, sports, business and entrepreneurship. The change is two-fold. It would give focus not only to the curriculum enhancement but also to the transition management. The intention of the $\mathrm{K}$ to 12 Curriculum is not merely to add two years of schooling but to enhance the basic education curriculum.

Changes to the curriculum are occurring at all levels and across all subjects. English is one of the subjects affected and indeed the importance of English within the curriculum is greatly emphasized. Furthermore, it assumes a high degree of importance with governments and indeed parents perceive that a mastery of the English language is an indispensable tool for technological development, international communication and access to a career.

Undoubtedly, the rapid changes and increased complexity of today's world present new challenges and put new demands on the educational system. There has been a growing awareness of the necessity to change and improve the preparation of students for productive functioning in the 
continually changing and highly demanding environment. In confronting this challenge, it is necessary to consider the complexity of the educational system itself and the multitude of problems that must be addressed. Clearly, no simple, single uniform approach can be applied with the expectation that significant improvements of the system will occur.

Change does not only affect the school system but also the people involved in the change. Also, change is viewed as having a direct impact on individuals; therefore, individuals' perception, attitudes, and concerns must be considered toward the implementation of an innovation [2], and appropriate interventions and support should be provided. Understanding change and its effect is important in facilitating a change process.

Those having to implement the educational changes taking place are the teachers within the public education system, who have to adopt new ideologies and implement them in their teaching, since they are responsible for passing on the changes through their teaching to their students. This double demand puts the teachers under strain, where the changes occurring represent a major shift in beliefs and practices, and can threaten successful implementation unless necessary logistical and professional conditions are met.

The results of the studies of [3], [4] on the stages of concern of teachers in Science and Mathematics respectively showed that most of the teachers are still at Stage 0 which indicates that teachers demonstrate lack of awareness and knowledge about the changes brought about by the $\mathrm{K}$ to 12 curriculum. Despite these alarming findings, teachers' concerns have never been addressed as factors in the implementation of the $\mathrm{K}$ to 12 English Curriculum.

It is in this context that the researchers were encouraged to determine and analyze also the concerns of the Grade 8 teachers in the implementation of the $\mathrm{K}$ to 12 English Curriculum to properly address their concerns through an appropriate training program for the effective implementation of the said curriculum.

\section{OBJECTIVES OF THE STUDY}

This study aimed to develop a proposed training program based on the analysis of the stages of concerns (SoC) of the Grade 8 teachers in the implementation of the $\mathrm{K}$ to 12 English Curriculum.

Likewise, it sought to describe the socio-demographic profile of the Grade 8 teachers in English in terms of age, sex, years of teaching experience, educational attainment, and number of seminars, trainings, and crash courses attended related to the implementation of the $\mathrm{K}$ to 12 English Curriculum. It also endeavored to determine the relationship between the socio-demographic profile of the Grade 8 teachers and their SoC in the implementation of the $\mathrm{K}$ to 12 English Curriculum.

\section{SIGNIFICANCE OF THE STUDY}

The findings of this study would enable the Grade 8 teachers in English to assess and reflect on their professional strengths and developmental needs and concerns in the implementation of the $\mathrm{K}$ to 12 English Curriculum. These could also help them determine specific programs, crash courses or trainings they need to undergo in order to further enhance their knowledge and skills to meet the content and performance standards of the new curriculum.

Meanwhile, the proposed training program developed in this study could address the teachers' concerns in the implementation of the $\mathrm{K}$ to 12 English Curriculum. Hence, their awareness and involvement in the implementation of the said curriculum and its implementation could be raised.

Moreover, the results of this study could encourage school administrators to extend maximum support to their teachers in attending trainings and seminars related to the $\mathrm{K}$ to 12 English Curriculum and its implementation.

Likewise, the findings of this study could be used by policy makers to facilitate the change process in schools. Not all innovations, such as the $\mathrm{K}$ to 12 English Curriculum, find their way into actual daily practice in classrooms unless the implementation is monitored and appropriate interventions are provided. Personalizing the K to 12 English Curriculum by identifying the teachers' concerns is the key to successful intervention. Specifically, the results of the study would make the policy makers understand teachers' concerns, perceptions, and attitudes toward the implementation of the $\mathrm{K}$ to 12 English Curriculum. Hence, they could make appropriate decisions on when and how to provide support to the teachers. Also, the findings of this study could contribute to the development of new policies to guide change to a point of effective implementation.

Furthermore, results from this study could serve as baseline for curriculum makers in creating critical changes to further accelerate, broaden, deepen, and sustain the improved education efforts already started to conform to the demands of students for higher learning endeavours and global competitiveness. The results could help the curriculum makers in identifying factors that affect the implementation of the new curriculum.

Finally, the study, itself, could serve as reference material to other research enthusiasts so that they could be guided and inspired to explore and study more on the SoC of teachers.

\section{THEORETICAL AND CONCEPTUAL FRAMEWORK}

This study was anchored Concerns Development Theory of [5] in which the assessment of teachers' concerns about an innovation or change is generally based on. This theory asserts that teachers pass through three phases of concerns about teaching as they mature as teachers. These three phases are characterized by teachers' concerns about self-survival as a teacher, the task of teaching, and their impact upon pupils. The phases are viewed as being sequential and accumulative in their evolution. In each phase of teacher development, all three types of concerns about teaching are felt by teachers, but the interaction between the pre-service or in-service setting and the teachers' particular stage of career development is one of the types of concern that demands the major focus of the teachers' attentions during each of the three phases of development.

During the early pre-service teacher preparation period, prospective teachers lack concern about teaching, have little understanding of pupils, and are concerned of their own survival as students. Later pre-service experiences result in 
the emergence of concerns about teaching with the central focus of the prospective teachers' attentions becoming self-survival as teachers. The nature of late pre-service experiences results an increase in the prospective teachers' concerns about actually being able to perform the tasks of teaching. During the early in-service teaching years, self-survival concerns typically are successfully handled and the neophyte teachers' central focus becomes addressing their concerns about the tasks of actually teaching. Later in their in-service teaching years, the more mature teachers successfully deal with their early self-survival concerns and their concerns about the tasks of teaching sufficiently to begin addressing their concerns about having a meaningful and significant impact upon their learners.

The said theory developed an evidence-based conceptual framework, called the Concerns-based Adoption Model (CBAM), which applies to anyone experiencing change [5]-[8]. The model holds that people considering and experiencing change evolve in the kinds of questions they ask and in their use of whatever the change is.

In the field of education, CBAM has provided faculty developers with a useful conceptualization for supporting and facilitating individuals and/or groups in implementing innovations within classrooms and universities. Further, it provides a construct that helps measure, describe and explain the change process of teachers, who are adopting reformed curriculum materials or new instructional practices into their teaching [9]. In the model, the teachers can have concerns in different stages in the process of change. Based on these different concerns, they need differentiated support and guidance [10]-[13].

Indeed, the success of every innovation depends on those who use it. Thus, knowing the stages of concern of individuals in relation to a particular innovation is important to facilitate change. Users of the innovation have to be knowledgeable about it so they can fully implement it. Notably, change is not an automatic progression but can be facilitated by addressing concerns at each stage as they arise.

The Concerns Development Theory and CBAM, therefore, provided the researchers a reason to develop a proposed training program based on the analysis of the stages of concerns of the Grade 8 teachers in the implementation of the K to 12 English Curriculum. With the tenets of these theories, the researchers were inspired to conduct this present study.

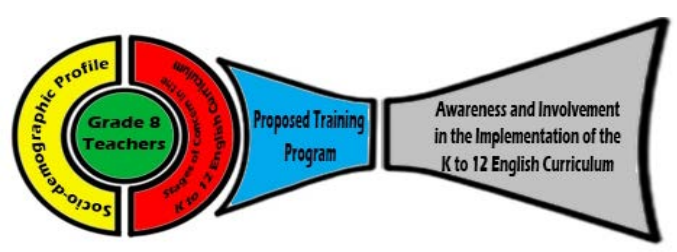

Fig. 1. Research Paradigm.

Based on Fig. 1, the researchers conceptualize the relationship between the Grade 8 teachers' SoC in the implementation of the $\mathrm{K}$ to 12 English Curriculum and their socio-demographic profile in terms of age, sex, years of teaching experience, educational attainment, and number of trainings, seminars, and crash courses attended related to the implementation of the $\mathrm{K}$ to 12 English Curriculum. This study believes that if the teachers' SoC are not properly addressed, failure in the implementation of the curriculum happens. Thus, an intervention support such as a training program may be proposed to raise the awareness and involvement of the Grade 8 teachers in the new curriculum.

\section{Methodology}

The study focused on the development and validation of a proposed training program to address the concerns of the Grade 8 teachers in the implementation of the $\mathrm{K}$ to 12 English Curriculum. Thus, this study made use of the Research and Development (R\&D) methodology.

Among the 91 Grade 8 teachers in English from the public secondary schools in the divisions of Laoag City and Ilocos Norte, who participated the K to 12 Regional Mass Training of Grade 8 Teachers in English held last May 15-19, 2013 at the Mariano Marcos State University College of Teacher Education (MMSU-CTE), Laoag City, 70 teachers were randomly selected as samples employing the purposive random sampling technique. This number was considered adequate to represent the whole population.

This study used a survey-questionnaire, Assessment Tool on SoC, which is composed of two parts. Part I of the survey-questionnaire obtained information about the Grade 8 teachers' socio-demographic profile, in terms of age, sex, educational attainment, years of teaching experience, as well as the number of seminars, trainings, and crash courses attended related to the implementation of the K to 12 English Curriculum. Meanwhile, Part II of the instrument contains the 35-item SoC Questionnaire of [2]. However, modifications were made in the instrument to suit the need of the study. This part of the survey-questionnaire gathered data on the Grade 8 teachers' stages of concern in the implementation of the $\mathrm{K}$ to 12 English Curriculum.

A 0 to 7 Likert-type scale was used to reflect the Grade 8 teachers' present concerns about their involvement in teaching the $\mathrm{K}$ to 12 English Curriculum. A researcher-made interview guide was also used in informal interviews with the Grade 8 teachers to supplement the results gathered from the survey-questionnaire. The interview guide helped assure the smooth flow of obtaining detailed information on the Grade 8 teachers' SoC in the implementation of the K to 12 English Curriculum.

Meanwhile, to determine the validity of the proposed training program, the Validation Instrument for Training Programs used by [14] was adapted, yet modified to suit the need of the study. The instrument consists of items that assessed the characteristics of the proposed training program in terms of its rationale, general objectives, content and methodology, manpower resources, budgetary allocation, and evaluation instrument.

Frequency, percentage, mean, and standard deviation were used to analyze the data collected on the socio-demographic profile of the Grade 8 teachers in English.

Meanwhile, frequency and percentage were used to determine the SoC of the teachers. Then, the Peak Stage Score Interpretation was utilized to identify the most intense Soc of each of the teachers. The total score in each stage was obtained by adding all the five item responses and was converted to percentile score using the SoC Raw Score-Percentile Conversion Chart. The stage with the highest percentile score was the most intense SoC of the 
teacher. The analysis of peak concern, most intense concern, was employed to identify the number of teachers who belong to high level of concern on each stage.

Pearson's $r$ correlation was used to determine the relationship between the Grade 8 teachers' SoC and their socio-demographic profile. To test the significance of the Pearson's $r$, the level of significance was set at $\alpha=0.01$.

Further, mean was used to determine the validity of the proposed training program.

\section{RESUltS AND DisCUSSION}

\section{A. Socio-demographic Profile of Grade 8 Teachers}

One of the concerns of this study is to describe the socio-demographic profile of the Grade 8 teachers in English in terms of age, sex, years of teaching experience, educational attainment, and number of seminars, trainings, and crash courses attended related to the implementation of the $\mathrm{K}$ to 12 English Curriculum. The data showing the socio-demographic profile of the Grade 8 teachers in English are presented in Table I.

TABLE I: SOCIO-DEMOGRAPHIC PROFILE OF GRADE 8 TEACHERS IN ENGLISH

\begin{tabular}{|c|c|c|c|c|}
\hline $\begin{array}{c}\text { Socio-demogra- } \\
\text { phic Profile }\end{array}$ & Characteristics & & Frequency & Percentage \\
\hline \multirow[t]{9}{*}{ Age } & $56-60$ & & 7 & 10.00 \\
\hline & $51-55$ & & 1 & 1.43 \\
\hline & $46-50$ & & 4 & 5.71 \\
\hline & $41-45$ & & 17 & 24.29 \\
\hline & $36-40$ & & 7 & 10.00 \\
\hline & $31-35$ & & 6 & 8.57 \\
\hline & $26-30$ & & 20 & 28.57 \\
\hline & $21-25$ & & 8 & 11.43 \\
\hline & $\begin{array}{c}\text { Mean }=37.31 \\
\text { years }\end{array}$ & $\begin{array}{c}\text { Total } \\
\text { Sd = } \\
10.57\end{array}$ & 70 & 100.00 \\
\hline \multirow[t]{3}{*}{ Sex } & Male & & 18 & 25.71 \\
\hline & Female & & 52 & 74.29 \\
\hline & & Total & 70 & 100.00 \\
\hline \multirow{8}{*}{$\begin{array}{c}\text { Years of } \\
\text { teaching } \\
\text { experience }\end{array}$} & $31-35$ & & 4 & 5.71 \\
\hline & $26-30$ & & 1 & 1.43 \\
\hline & $21-25$ & & 9 & 12.86 \\
\hline & $16-20$ & & 9 & 12.86 \\
\hline & $11-15$ & & 7 & 10.00 \\
\hline & $6-10$ & & 20 & 28.57 \\
\hline & $1-5$ & & 20 & 28.57 \\
\hline & Mean = 11.93 & $\begin{array}{l}\text { Total } \\
\text { Sd = } \\
8.67\end{array}$ & 70 & 100.00 \\
\hline \multirow{3}{*}{$\begin{array}{l}\text { Educational } \\
\text { attainment }\end{array}$} & BS & & 47 & 67.14 \\
\hline & MA units only & & 23 & 32.86 \\
\hline & & Total & 70 & 100.00 \\
\hline \multirow{4}{*}{$\begin{array}{l}\text { Number of } \\
\text { seminars, } \\
\text { trainings, and } \\
\text { crash courses } \\
\text { attended }\end{array}$} & 3 & & 10 & 14.29 \\
\hline & 2 & & 12 & 17.14 \\
\hline & 1 & & 48 & 68.57 \\
\hline & & Total & 70 & 100.00 \\
\hline
\end{tabular}

Findings show that the Grade 8 teachers in English have a mean age of 37.3. This finding implies that Grade 8 teachers in English of the public secondary schools of Laoag City and Ilocos Norte are dominated by middle-aged teachers. The data also show that the Grade 8 teachers are dominated by females (52 or $74.29 \%$ ). Their mean years of teaching experience is 11.93, which suggests that the teachers are somewhat still new in the field and yet to gain experience beneficial to their career. Majority (47 or 67.14\%) of them are BS holders, which implies that the teachers are still in the process of making some advancement in their education. Majority (48 or $68.57 \%$ ) of them, too, have attended only one training related to the implementation of the $\mathrm{K}$ to 12 English Curriculum. The findings recommend that more intensive trainings, seminars, and workshops have to be attended by the teachers to cope with the educational reforms.

Further, the result emphasizes the importance of conducting more trainings, seminars, and workshops for these could help the teachers acquire the needed competencies required of them for the new curriculum.

\section{B. Stages of Concern of the Grade 8 Teachers in the Implementation of the K to12 English Curriculum}

Another concern of this study is to determine the SoC of the Grade 8 teachers in English with regard to the implementation of the $\mathrm{K}$ to 12 English Curriculum. Table II shows the distribution of the Grade 8 teachers in English on their SoC based on the CBAM.

TABLE II: DISTRIBUTION OF THE GRADE 8 TEACHERS ACCORDING TO THEIR STAGES OF CONCERN

\begin{tabular}{ccc}
\hline Stages of Concern & Frequency & Percentage \\
\hline Stage 6 - Refocusing & 0 & 0.00 \\
Stage 5 - Collaboration & 0 & 0.00 \\
Stage 4 - Consequence & 0 & 0.00 \\
Stage 3 - Management & 1 & 1.43 \\
Stage 2 - Personal & 3 & 4.28 \\
Stage 1 - Informational & 15 & 21.43 \\
Stage 0 - Awareness & 51 & 72.86 \\
\hline Total & 70 & 100.00 \\
\hline
\end{tabular}

Of the 70 Grade 8 teachers, 51 (72.86\%) of them fall under Stage 0 (Awareness). This means that the teachers do not know what the $\mathrm{K}$ to 12 English curriculum is.

This also implies that the teachers are not concerned about the said curriculum since they are completely occupied with other things such as other initiatives, tasks, and activities, which their respective schools expect them to fulfill. According to the teachers, although they do not know about the $\mathrm{K}$ to 12 English Curriculum, they are concerned on finishing the target learning competencies indicated in the teaching-learning package of the curriculum. Hence, it can be deduced from the findings that the teachers are not aware of the new changes brought about by the new curriculum.

\section{Relationship between the Grade 8 Teachers' \\ Socio-demographic Profile and their Stages of Concern in the Implementation of the K to12 English Curriculum}

This study also sought to determine the relationship between the socio-demographic profile of the Grade 8 teachers and their SoC in the implementation of the $\mathrm{K}$ to12 English Curriculum. This is shown in Table III.

It can be gleaned from the table that age is significantly related to the SoC of the Grade 8 teachers, with correlation coefficient of 0.921 . This implies that the older the teacher is, the higher is his/her SoC in the implementation of the $\mathrm{K}$ to 12 English Curriculum.

Also, it can be seen from the table that teachers that the years of teaching experience of the Grade 8 teachers are 
significantly related to their SoC with correlation coefficient of 0.396. This means that teachers with more teaching experience develop concerns at impact levels, whereas teachers with the least teaching experience develop self-oriented concerns.

TABLE III: COEFFICIENT OF CORRELATION BETWEEN THE SOCIO-DEMOGRAPHIC PROFILE OF THE GRADE 8 TEACHERS AND THEIR STAGES OF CONCERN IN THE IMPLEMENTATION OF THE K TO 12 ENGLISH CURRICULUM

\begin{tabular}{cc}
\hline Variables & Stages of Concern \\
\hline Age & $0.921^{* *}$ \\
Sex & 0.053 \\
Years of Teaching Experience & $0.396^{* *}$ \\
Educational Attainment & $0.558^{* *}$ \\
Number of Seminars and Trainings & $0.341^{* *}$ \\
Attended & \\
\hline
\end{tabular}

** Significant at the 0.01 probability level

Critical Values: (two-tailed, df $=68, \alpha=.01$ ) $= \pm .307$

(two-tailed, $\mathrm{df}=68, \alpha=.01)= \pm .236$

It also appears that the correlation between the educational attainment of the teachers and their stages of concern is significant, as indicated by the correlation coefficient of 0.558 . The finding suggests that the higher the educational attainment of the teacher is, the higher is his/her SoC.

Further, the results reveal that the number of trainings and seminars attended by the Grade 8 teachers is significantly related to the teachers' SoC. This means that the teachers, who have more trainings and seminars on the implementation of the K to 12 English Curriculum, tend to have higher SoC.

Results reveal that there is no significant relationship between the sex of the teachers and their SoC. Whether the teacher is male or female, his or her sex is not contributory to the teachers' SoC.

\section{Training Program for Grade 8 Teachers: Raising the \\ Teachers' Awareness and Involvement in the Implementation of the K to 12 English Curriculum}

The proposed training program was developed as a result of the findings on the stages of concern of the Grade 8 teachers in the implementation of the $\mathrm{K}$ to 12 English Curriculum. This training program dubbed as Training Program for Grade 8 Teachers: Raising the Teachers' Awareness and Involvement in the Implementation of the $\mathrm{K}$ to 12 English Curriculum by the Department of Education (DepEd) is believed to address the concerns of the said teachers. It includes the following parts: training program information which provides a quick information about the proposed training program; rationale of the training program which gives an overview why the training program is proposed; general objectives which pertain to the outcomes that the participants of the training program are expected to fulfill; content and methodology which deal with the sequence of activities, specific objectives, presentation strategies, and materials for the training program; manpower resources which encompass the resource speakers, the roles and responsibilities of the training program staff and the training program support staff; budgetary allocation which includes details about the expected expenses that shall be incurred during the training program; and evaluation instrument is a tool to be used by the participants in evaluating the effectiveness of the proposed training program.

\section{1) Rationale}

The 1987 Philippine Constitution puts special premium on education and accords it with the highest budgetary priority. Article XIV, Section I, in particular, explicitly provides: “The State shall protect and promote the right of all citizens to quality education at all levels." Article XIV, Section V clearly mandates the State to assign the highest budgetary priority for education. However, despite these constitutional guarantees, current performance indicators showed a dismal picture of the quality of education in the country.

According to DepEd, the congested curriculum is partly blamed for this bleak situation. Another reason behind the poor quality of the educational system in the country is that teachers' concerns have never been addressed as factors in the innovation of the curriculum implementation.

In a study conducted on the SoC of the Grade 8 teachers in the implementation of the K to 12 English Curriculum, it was found out that most of them are still in Stage 0 (Awareness), which means that they have little concern about or involvement in the implementation of the said curriculum. To achieve the goals and objectives of the new curriculum, there is a need to extend support and assistance to the teachers who are considered the agents of change.

Hence, the proposed training program aims to raise the awareness and involvement of the Grade 8 teachers in the implementation of the K to 12 English Curriculum.

\section{2) General objectives}

At the end of the five-day training program, the participants should be able to: a) familiarize themselves with the framework, philosophies, and methodologies pertinent to the $\mathrm{K}$ to 12 English Curriculum for Grade 8; b) equip themselves with the necessary knowledge and skills on the use of the different instructional strategies and assessment techniques in the implementation of the curriculum; c) use available resources in the implementation of the $\mathrm{K}$ to 12 English curriculum; d) demonstrate favorable values that could guide them in the effective implementation of the curriculum; and e) initiate motivation, sense of self-reflection, and self-awareness about the curriculum.

\section{3) Content and methodology}

The proposed training program will be conducted for five consecutive Saturdays. Eight hours will be allotted for each day.

Sessions shall be conducted in seminar method, coupled with team-teaching and group workshops. Such method shall be used, since it will involve a group of people coming together for the discussion and learning of topics related to the implementation of the K to 12 English Curriculum.

Experts, who are along the area of English and who have attended trainings and seminars about the $\mathrm{K}$ to 12 English Curriculum, will serve as trainers in the proposed training program. Suggested time durations are also included in the design of the training program to assure the smooth flow of the sessions. However, these are only tentative and may be modified as the need arises. Specific objectives, presentation strategies, and materials are likewise included in the design. Reflection sessions are included at the end of each training day to allow participants to wrap up what they have learned and that they will become more aware of the objectives of each session. Handouts shall also be distributed during the conduct of the training. Thus, these materials are to be prepared in advance. 
The matrix of the training program shows the design of the proposed schedule of activities of the training program developed. It contains the following: a) specific objectives; b) session topics; c) day and time allotment; d) presentation strategies/activities; e) materials needed in each session.

On the first day, the Grade 8 teachers should be able to draw out implications of the issues related to the challenges that beset the Philippine educational system; differentiate the old and the existing curricula of the country; determine ways on how to sustain curriculum change; and reflect on their concerns and beliefs and the implications of these in their classroom practices. Activities shall include an opening program which will present the rationale and objectives of the training program as well as the trainers and participants; and discussion of topics on "The Challenge of the 21st Century", "21st Century Skills”, and “ASEAN Integration."

The second day, on the other hand, aims to identify the importance of motivation, awareness and mentoring in the implementation of the new curriculum; discuss the components and features of the K to 12 English Curriculum; explain the Framework of the K to 12 English Curriculum, particularly the language theories, language learning views, and approaches and strategies in language teaching embedded in the framework; and reflect on the important features of the $\mathrm{K}$ to 12 English Curriculum based on its framework. Topics on "Mentoring Teachers for Change", "Integrated Language Arts Curriculum of the K to 12 English Curriculum”, “The K to 12 English Curriculum Framework”, "Revisiting the Curriculum", "Championing Change”, and "How Beliefs and Concerns Shape Teaching" will be discussed.

On the third day, the participants should be able to identify the content and performance standards of the K to 12 English Curriculum, particularly Grade 8; unpack content and performance standards to learning competencies; construct performance tasks and assessment tool prototypes, which can be used in assessing student learning outcomes; write weekly lesson logs for prototypes; and reflect on the importance and effects of planning for instruction. The following topics will be carried out: "Closer Look on the Content and Performance Standards of the K to 12 English Curriculum (with particular focus on Grade 8 English)" and "Unpacking the Standards of $\mathrm{K}$ to 12 English for Grade 8 Assessing Student Learning Outcomes." The participants will be asked to write weekly lesson log prototypes for Grade 8 English.

The fourth day of the training strives to identify available materials in the teaching of the $\mathrm{K}$ to 12 English Curriculum; evaluate the parts of the materials available; generate instructional plans based on the existing materials; and reflect on the importance familiarizing the use of available materials in the implementation of the K to 12 English Curriculum for Grade 8. The teachers will be instructed to walkthrough the learning package and teaching guide of Grade 8 English and develop instructional plans.

Meanwhile, the last day aims to use the available materials of $\mathrm{K}$ to 12 English for Grade 8; assess their strengths and weaknesses in the use of the available materials; and formulate personal commitment in the implementation of the $\mathrm{K}$ to 12 English Curriculum for Grade 8, and recapitulate the different activities and sessions attended in the training program. The participants will have their demonstration teaching. Further, they will be asked to assess the training program using the evaluation instrument.

ICT-based materials shall be used in the delivery of the topics. Large and small group tasks shall be implemented to achieve the objectives. At the end of each day, the participants will be asked to write their reflections on the topics discussed.

\section{4) Manpower resources}

The suggested trainers in the five-day training will be experts along the area of English and will be those who attended trainings and seminars about the $\mathrm{K}$ to 12 English Curriculum.

The training program staff will be organized in coordination with the Department of Education. This includes one program manager, one training coordinator, one administrative assistant, two training facilitators, and two training hosts.

\section{5) Budgetary allocation}

The budgetary allocation shall finance the expenses of the five-day training program. The expenses shall cover the food for the participants and the trainers, rental of venue and facilities, honorarium of the trainers, training program staff and support staff, incidental expenses, administrative cost, and training materials. All in all, the budget for the training program shall be Php325, 000.

\section{6) Evaluation instrument}

Part I of the evaluation instrument will require the participants to evaluate the training program along the following components: Topics; Trainers; Participants' Involvement; Facilities; Time Management; Food; and Overall Training Evaluation. The evaluation instrument shall have a scale of 1-5.

Part II of the evaluation form will require the participants to answer the open-ended questions about the training program attended.

\section{E. Validity of the Proposed Training Program in}

Addressing the Grade 8 Teachers' Concerns in the Implementation of the K to 12 English Curriculum

Table IV shows the result on the validity of the proposed training program.

It can be gleaned from the table that the rationale of the proposed training program is very highly valid, with a component mean of 4.83. The rationale of the proposed training program clearly gives an overall view of the training and is stated briefly. Furthermore, the rationale conforms to the objectives and activities of the program. Hence, the rationale of the proposed training program is valid.

The table also shows that the general objectives of the proposed training program are very highly valid, as indicated by the component mean of 4.86. The proposed training program's objectives are specific, attainable, observable, and measurable, which are standards or qualifications of good objectives. Moreover, the objectives are clearly stated and are arranged logically.

It can also be gleaned from the table that the content and methodology of the proposed training program are very highly valid, as manifested by the component mean of 4.89 . The content and methodology of the proposed training program address the concerns of the Grade 8 teachers. Likewise, they clearly describe the program of activities to be undertaken. Further, they present a reasonable scope of 
activities that can be conducted within the time frame and resources of the proposed training program.

TABLE IV: RESULTS ON THE VALIDATION OF THE PROPOSED TRAINING PROGRAM

\begin{tabular}{lcc}
\multicolumn{1}{c}{ Criteria } & Mean & $\begin{array}{c}\text { Descriptive } \\
\text { Interpretation }\end{array}$ \\
\hline $\begin{array}{l}\text { A. Rationale } \\
\text { The rationale of the training program: }\end{array}$ & \\
$\begin{array}{l}\text { 1. clearly gives an over-all view of the } \\
\text { intensive training program; and }\end{array}$ & 5.00 & VHV \\
2. conforms to the activities presented. & 4.67 & VHV \\
Component Mean & 4.83 & VHV \\
\hline B. General Objectives & & \\
The general objectives of the training & & \\
program: & & \\
1. are specific; & 4.67 & VHV \\
2. are measurable; & 4.67 & VHV \\
3. are attainable; & 4.67 & VHV \\
4. are realistic; & 5.00 & VHV \\
5. are time-bound; & 5.00 & VHV \\
6. are clearly stated; and & 5.00 & VHV \\
7. are arranged in logical manner. & 5.00 & VHV \\
Component Mean & 4.86 & VHV \\
\hline
\end{tabular}

\section{Content and Methodology}

The content and methodology of the training program:

1. address the needs of the participants;. $\quad 5.00 \quad$ VHV

2. clearly describe program activities; $4.67 \quad$ VHV

and

3. present a reasonable scope of

activities that can be conducted within

the time and resources of the program.

Component Mean

D. Manpower Resources

The manpower resources of the training

program:

1. are detailed in terms of the specific

roles and responsibilities that each

member is expected to perform;

2. clearly determine and describe the

proposed resource speakers; and

3. are specific in terms of the number of

the members for the training program

support staff.

Component Mean

VHV

4.89

VHV

\section{E. Budgetary Allocation}

The budgetary allocation of the training program:

1. is detailed in all aspects;

VHV

2. provides list of expected costs that

will be incurred at the time of the

training program; and

3. contains no unexplained amounts or

miscellaneous contingency.

Component Mean

$5.00 \quad$ VHV

$4.67 \quad$ VHV

5.00

4.89

VHV

VHV

\section{F. Evaluation Instrument}

The evaluation instrument of the

training program:

1. assesses the different components of

the training; and

2. could be easily administered, scored,

and interpreted.

Component Mean

Legend: Range Interval Descriptive Interpretation

4.51-5.00 Very Highly Valid (VHV)

3.51-4.50 Highly Valid (HV)

2.51-3.50 Moderately Valid (MV)

1.51-2.50 Slightly Valid (SV)

1.00-1.50 Not Valid (NV)

The table further shows that the evaluators rated the manpower resources of the proposed training program as very highly valid, as shown by the component mean of 4.89 . The manpower resources of the proposed training program is detailed in terms of the specific roles and responsibilities that the members of the training program staff and training program support staff are expected to perform. Also, the manpower resources clearly determine and describe the proposed resource speakers, as well as the number of members in the training program support staff.

As also shown in the table, the evaluators considered the budgetary allocation of the proposed training program very highly valid, as revealed by the component mean of 4.89 . The budgetary allocation of the proposed training program is detailed in all aspects, provides list of expected costs that shall be incurred at the time of the training, contains no unexplained amounts for miscellaneous or contingency. Hence, the evaluators agreed that budgetary allocation for the conduct of the training program is valid.

Meanwhile, it can also be gleaned from the table that the evaluation instrument of the proposed training program is very highly valid, as manifested by the component mean of 5.00. According to the evaluators, the evaluation instrument of the proposed training program could assess the different components of the training. Furthermore, it could be easily administered, scored, and interpreted. Hence, the evaluation instrument of the proposed training program is valid.

With all the indicated results, the conduct of the proposed training program would be very beneficial in raising the awareness and involvement of the Grade 8 teachers in the implementation of the $\mathrm{K}$ to 12 English Curriculum. Thus, the proposed training program is feasible for use and should be pursued.

\section{CONCLUSIONS}

In the light of the findings, it can be concluded that majority of the Grade 8 teachers in English of the Divisions of Laoag City and Ilocos Norte lack awareness, concern, and involvement in the implementation of the $\mathrm{K}$ to 12 English Curriculum, as indicated by their stage of concern at Stage 0 (Awareness).

It can also be concluded that a significant relationship exists between the Grade 8 teachers' stages of concern and their age, years of teaching experience, educational attainment, and number of trainings and seminars attended related to the implementation of the $\mathrm{K}$ to 12 English Curriculum.

Further, the proposed training program is valid in terms of its rationale, general objectives, content and methodology, manpower resources, budgetary allocation, and evaluation instrument. Thus, it could be used by DepEd to address the concerns of the Grade 8 teachers in the implementation of the $\mathrm{K}$ to 12 English Curriculum.

\section{RECOMMENDATIONS}

In the light of the findings and conclusions, several recommendations are offered to DepEd officials, school principals, head teachers, teachers, and other researchers.

The proposed training program should be tried out by higher DepEd authorities, school principals, and head teachers in order to raise the awareness and involvement of the Grade 8 teachers in the implementation of the $\mathrm{K}$ to 12 English Curriculum. 
For effective implementation of the $\mathrm{K}$ to 12 English Curriculum, classroom visits, mentoring, and consultative meetings should be done so that the teachers can internalize the significance of the said curriculum, not only to the lives of their students, but also to the improvement of their teaching skills and classroom practices.

Researches on SoC of Grade 7 and Grade 9 teachers in English and other subjects should also be conducted to come up with appropriate intervention programs and activities that could address their concerns in the implementation of the $\mathrm{K}$ to 12 Curriculum, in general.

\section{REFERENCES}

[1] Department of Education (2012). Discussion paper on the enhanced K $+\quad 12$ basic education program. [Online]. Available: http://ceap.org.ph/upload/download/201112/1911148430_1.pdf.

[2] G. E. Hall and W. L. Rutherford, "Levels of use of the innovation: a framework for analyzing innovation adoption,” Journal of Teacher Education, vol. 26, no. 1, 1975.

[3] R. A. Reyes, "Levels of use and stages of concern of grade 7 teachers in the adoption of the $\mathrm{k}$ to 12 life sciences curriculum," Unpublished Master's Thesis. Mariano Marcos State University, 2014.

[4] E. B. Natividad, "Teachers' beliefs, stages of concern, and levels of use of the k to 12 mathematics curriculum,” Unpublished Master's Thesis. Mariano Marcos State University, 2014.

[5] F. F. Fuller, "Concerns of teachers: A developmental conceptualization,” American Educational Research Journal, vol. 6, no. 2, pp. 207-226, 1969.

[6] G. E. Hall, "The concerns-based approach to facilitating change," Educational Horizons, Summer, vol. 57, no. 4, pp. 202-208, Austin, TX: Research and Development Center for Teacher Education, The University of Texas. (ERIC Document Reproduction Service No. ED147), 1979.

[7] G. E. Hall, R. C. Wallace, and W. A. Dossett, "A developmental conceptualization of the adoption process within educational institutions (Report No. 3006)," Austin: The University of Texas at Austin, Research and Development Center for Teacher Education. (ERIC Document Reproduction Service No. ED 095 126), 1973.

[8] G .E. Hall and S. F. Loucks, "Innovation configurations: Analyzing the adaptations of innovations," Austin: The University of Texas at Austin, Research and Development Center for Teacher Education, 1978.

[9] G. E. Hall, S. F. Loucks, W. L. Rutherford, and B. W. Newlove, "Levels of use of the innovation: A framework for analyzing innovation adoption,” Journal of Teacher Education, vol. 26, no. 1, 1975.

[10] M. Anderson and K. Anderson, Text Types in English 1, Malaysia: MacMillan, 2003.
[11] S. M. Hord, "A manual for using innovation configurations to assess teacher development programs," Austin: University of Texas, Research and Development Center for Teacher Education, 1986.

[12] S. M. Hord, W. L. Rutherford, L. Huling-Austin, and G. E. Hall. "Taking charge of change," Alexandria, VA: Association of Supervision and Curriculum Development, 1987.

[13] S. M. Hord, S. M. Stiegelbauer, G. E. Hall, and A. A. George (2006). Measuring implementation in schools: Innovation configurations, Austin, TX: SEDL. [Online]. Available: http://www.sedl.org/pubs/catalog/items/cbam19.html.

[14] I. L. Najorda, "Gender-Related concepts and teaching behavior of faculty of teacher education programs: Database for a training design," MA Thesis, Mariano Marcos State University, 2005.

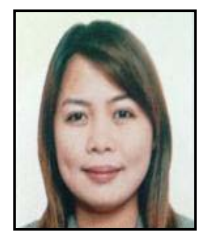

Winicel May C. Ancheta is from Laoag City, Ilocos Norte, Philippines. She was born on May 19, 1988. She earned her master of arts degree in education majored in language and at the Mariano Marcos State University (MMSU) Graduate School, Laoag City, Philippines in 2016.

At present, she is a teacher III at Ilocos Norte College of Arts and Trades which is located at the City of Laoag. She is taking up doctor of philosophy in developmental education at Divine Word College of Laoag.

Ms. Ancheta is a member of the Asian Educational Research Association.

Ronald Candy S. Lasaten is from the City of Batac, Ilocos Norte, Philippines. He was born on January 16, 1981. He earned his doctor of philosophy degree in applied linguistics at the Mariano Marcos State University (MMSU) Graduate School, Laoag City, Philippines in 2012

He is presently an English professor at the Mariano Marcos State University College of Teacher Education (CTE), Laoag City. He is the college coordinator for instructional materials development, coordinator for Board Licensure Examination for Professional Teachers (BLEPT) reviewer and the editor-in-chief of the CTE Research Journal. His research interests include linguistics, language, literature, language and literature teaching, language and literature assessment, instructional materials development and integration of ICT in education.

Dr. Lasaten is the vice president for Research of the Association of Teacher Education Administrators (ATEA), a member in Asian Qualitative Research Association (AQRA), Philippine Association for Teacher Education (PAFTE), and International English Learners Training Institute (IELTI). 